\title{
おとり型核酸医薬による慢性関節リウマチに 対する遺伝子治療
}

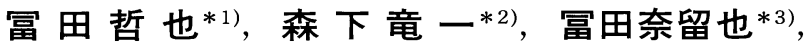 \\ 金田安史*2)，吉川秀樹*1)，越智隆弘*4)
}

\section{review article}

INFLAMMATION AND REGENERATION

\section{Application of $N F \varkappa B$ decoy oligonucleotides for arthritis as a gene therapy}

Rheumatoid arthritis(RA) and collagen-induced arthritis(CIA) are characterized by hyperplasia of the synovium and progressive joint destruction. The transcription factor $-\varkappa \mathrm{B}(\mathrm{NF} \varkappa \mathrm{B})$ plays apivotal role in the coordinated transactivation of cytokine and adhesion molecule genes, whose activation has been postulated to be involved in destructive changes of articular cartilage and bone in arthritic joints. In particular, interleukin-1(IL-1) and tumor necrosis factor $\alpha(\mathrm{TNF} \alpha)$ are important cytokines which perpetuate arthritis and induce joint destruction in both rheumatoid arthritis and collagen-induced arthritis. We hypothesized that synthetic double-stranded DNA high affinity for $\mathrm{NF} \varkappa \mathrm{B}$ could be introduced in vivo as "decoy" cis elements to bind the transcription factor and to block the activation of proinflammatory cytokine genes such as IL-1 and TNF $\alpha$. We reported here that in vivo transfection of $\mathrm{NF} \varkappa \mathrm{B}$ decoy ODN by intraarticular injection into collagen-induced arthritis in rats improved paw swelling. Histologic and radiographic studies showed a marked suppression of joint destruction in ankles treated by $\mathrm{NF} \varkappa \mathrm{B}$ decoy ODN transfection. $\mathrm{NF} \varkappa \mathrm{B}$ decoy ODN also suppressed the production of IL-1 and TNF $\alpha$ by synovium in the arthritic joints. Results demonstrated that administration of $\mathrm{NF} \varkappa \mathrm{B}$ decoy ODN in arthritic joints of collagen-induced arthritis in rats led to amelioration of arthritis. These findings suggest that intraarticular transfection of $\mathrm{NF} \varkappa \mathrm{B}$ decoy ODN may provide a useful therapeutic strategy for inflammatory arthritis.

\section{Rec. 2/8/2001, pp 101 108 \\ Tetsuya Tomita ${ }^{* 1)}$, Ryuichi Morishita*2), Naruya Tomita ${ }^{* 3)}$, Yasufumi Kaneda ${ }^{* 2)}$, Hideki Yoshikawa*1), Takahiro Ochi*4) \\ key words : rheumatoid arthritis, decoy, $N F_{\varkappa} B$, gene therapy, transcriptional factor}

*1) Department of Orthopaedic Surgery, ${ }^{* 2)}$ Division of Gene Therapy Science, ${ }^{* 3)}$ Department of Geriatric Medicine, ${ }^{* 4)}$ Division of Computer Integrated Orthopaedic Surgery, Osaka University Graduate School of Medicine *11 大阪大学大学院医学系研究科器官制 御外科, ${ }^{* 2}$ 同 遺伝子治療学, ${ }^{* 3)}$ 同 加蔽医学, ${ }^{* 4)}$ 同 医 工学治療学

Offprint requests to : Tetsuya Tomita, Department of Orthopaedic Surgery, Osaka University Graduate School of Medicine, 2-2 Yamadaoka, Suita, Osaka 561-0871, Japan
慢性関節リウマチ (rheumatoid arthritis：RA) は慢性炎症性疾患であり, 関節破壊が臨床上大き な問題となっている。既存の薬剤では関節破壊抑 制効果はほとんど認められず，最近ではさまざま な抗 RA 剤, 免疫抑制剤, NSIAD などの組み合わ せにより, 血清学的には炎症反応もある程度コン トロールされるようにはなってきてるが，このよ うな状態でも全身のいくつかの関節は関節腫脹が 持続し, 経時的に関節破壊が進行する患者は決し て少なくない，腫脹関節局所での骨・軟骨破壊進 


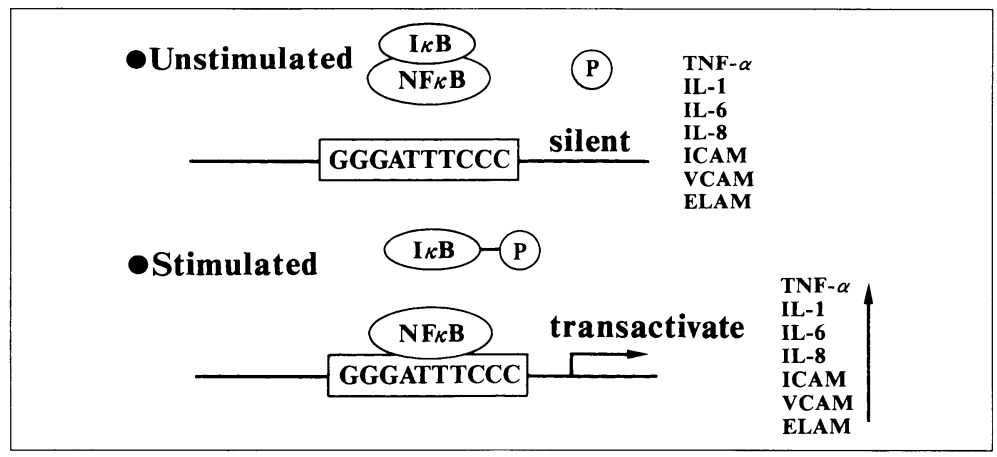

図 $1 \mathrm{NF} \varkappa \mathrm{B}$ の活性化機序

未刺激状態では $\mathrm{NF} \varkappa \mathrm{B}$ は $\mathrm{I} \varkappa \mathrm{B}$ と結合している。刺 激を受けると $\mathrm{I} \varkappa \mathrm{B}$ がリン酸化され， $\mathrm{NF} \varkappa \mathrm{B}$ は核内 へ移行し，結合部位に結合することにより活性化さ

れ，さまざまな因子の遺伝子発現を活性化する。

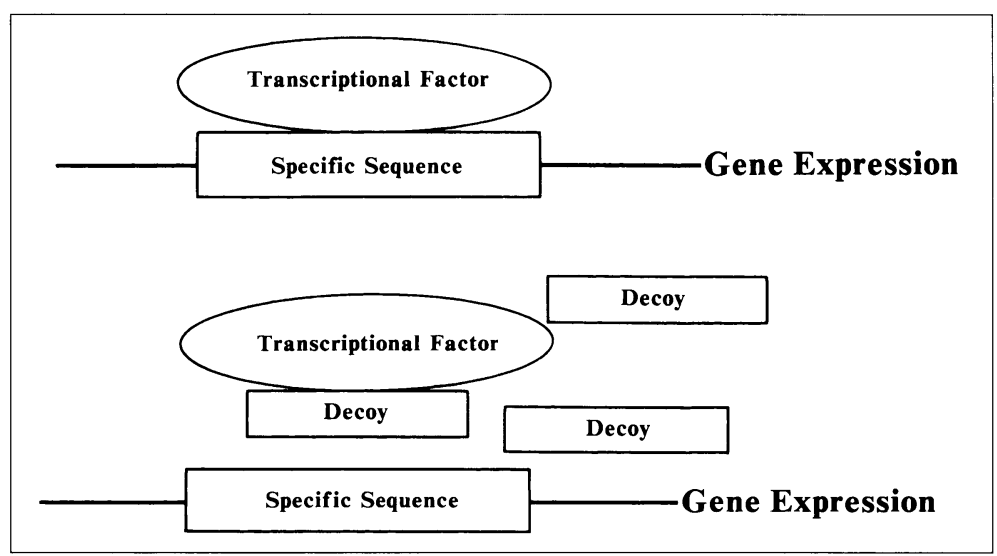

図 2 おとり型核酸医薬(デコイ)の作用機序

デコイはその特定の結合部位に競合的に結合し，転 写調節因子の結合阻害によるプロモーター活性の低 下を生じさせる.

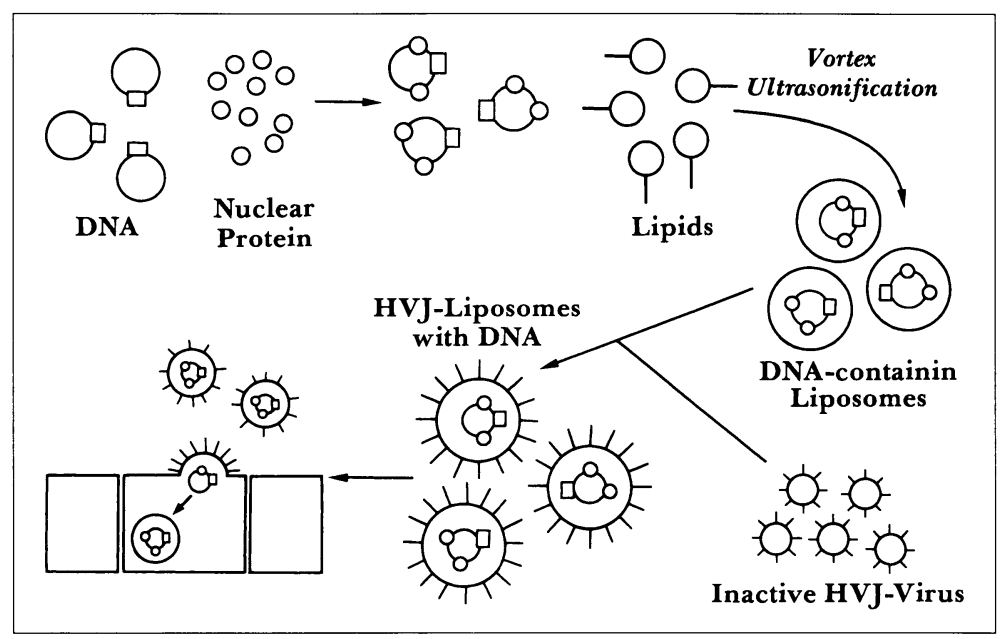

図 3 HVJ-リポゾーム法 
行の抑制が可能な治療法の開発は必須と考えられ る.

RA の特徵の一つは, 関節局所における細胞浸 潤と血管新生を伴う滑膜増殖である。RAの関節 破壊機序は未だ完全には解明されてはいないが, 増殖滑膜も重要な役割を果たしていると考えられ ている. 関節局所では IL-1 $\beta$, TNF $\alpha$, IL- 6, IL8 などの炎症性サイトカインや ICAM-1 などの 接着因子, matrix metalloproteinase (MMP)など が過剰に産生され RA の骨・軟骨破壊に関与して いる，RAの治療としてこれら炎症性サイトカイ ンや接着因子の抗体を用い病態を改善しょうとす る治療が注目を集めている。特に TNF $\alpha$ をー ゲットとした抗体療法は上トでもその有効性が示 されている1 5).

また実験的関節炎モデルや臨床試験では IL-1 をターゲットとした IL-1 Raによる治療も関節 破壊抑制に効果的であることが報告されてい る ${ }^{6 \sim 10)}$. しかしながらこれら抗体療法にも投与法, 効果持続, コストなどさまざまな問題点が残存し ているのが現状である.

筆者らはこれらの因子の発現を制御している転

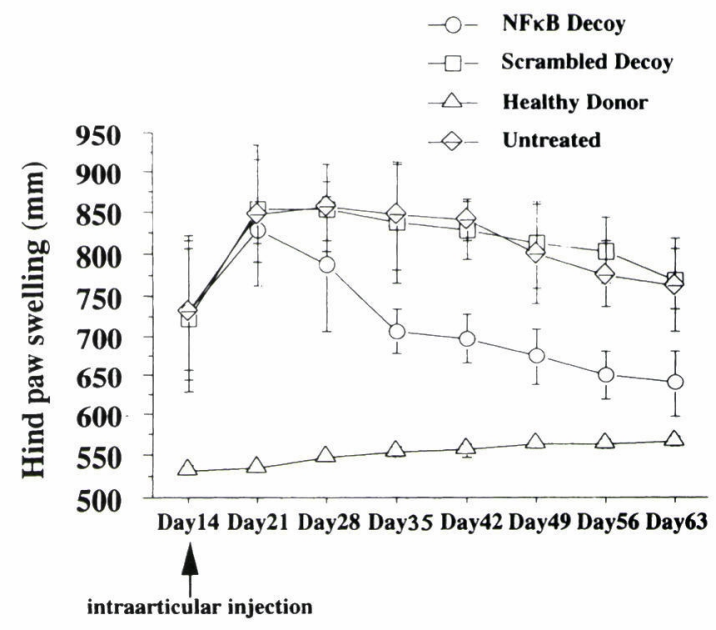

図 4 CIA ラット足関節腫脹の経時的変化

$\mathrm{NF} \varkappa \mathrm{B}$ デコイ投与後 2 週より足関節腫脹は改善した.

写制御因子 nuclear factor $\varkappa \mathrm{B}(\mathrm{NF} \varkappa \mathrm{B})$ に着目し た. $\mathrm{NF}$ 列 は免疫グロブリン $\mathrm{k}$ 鎖遺伝子が成熟 $\mathrm{B}$ 細胞特異的に発現するために必要なエンハンサー 領域に結合する転写因子として同定された ${ }^{11)}$. p 50 と p 65 のへテロ二量体であることが明らか になっている。不活化の状態ではその抑制因子 $\mathrm{I} \varkappa \mathrm{B}$ と複合体を形成し, 細胞質に存在するが, 細
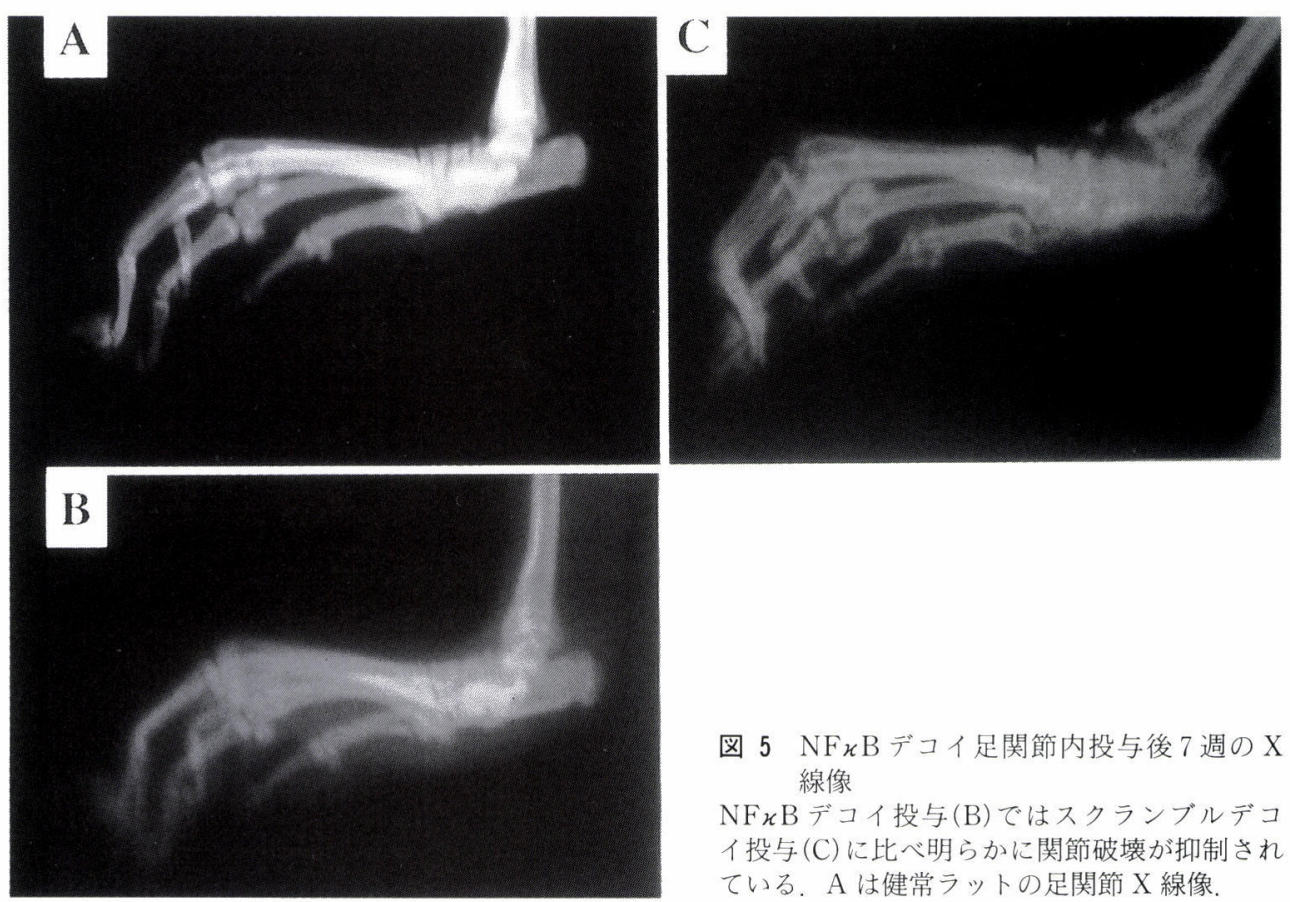

図 $5 \mathrm{NF} \varkappa \mathrm{B}$ デコイ足関節内投与後 7 週の $\mathrm{X}$ 線像

$\mathrm{NF} \varkappa \mathrm{B}$ デコイ投与 $(\mathrm{B})$ ではスクランブルデコ イ投与 (C) に比べ明らかに関節破壊が抑制され ている。 A は健常ラットの足関節 X 線像. 


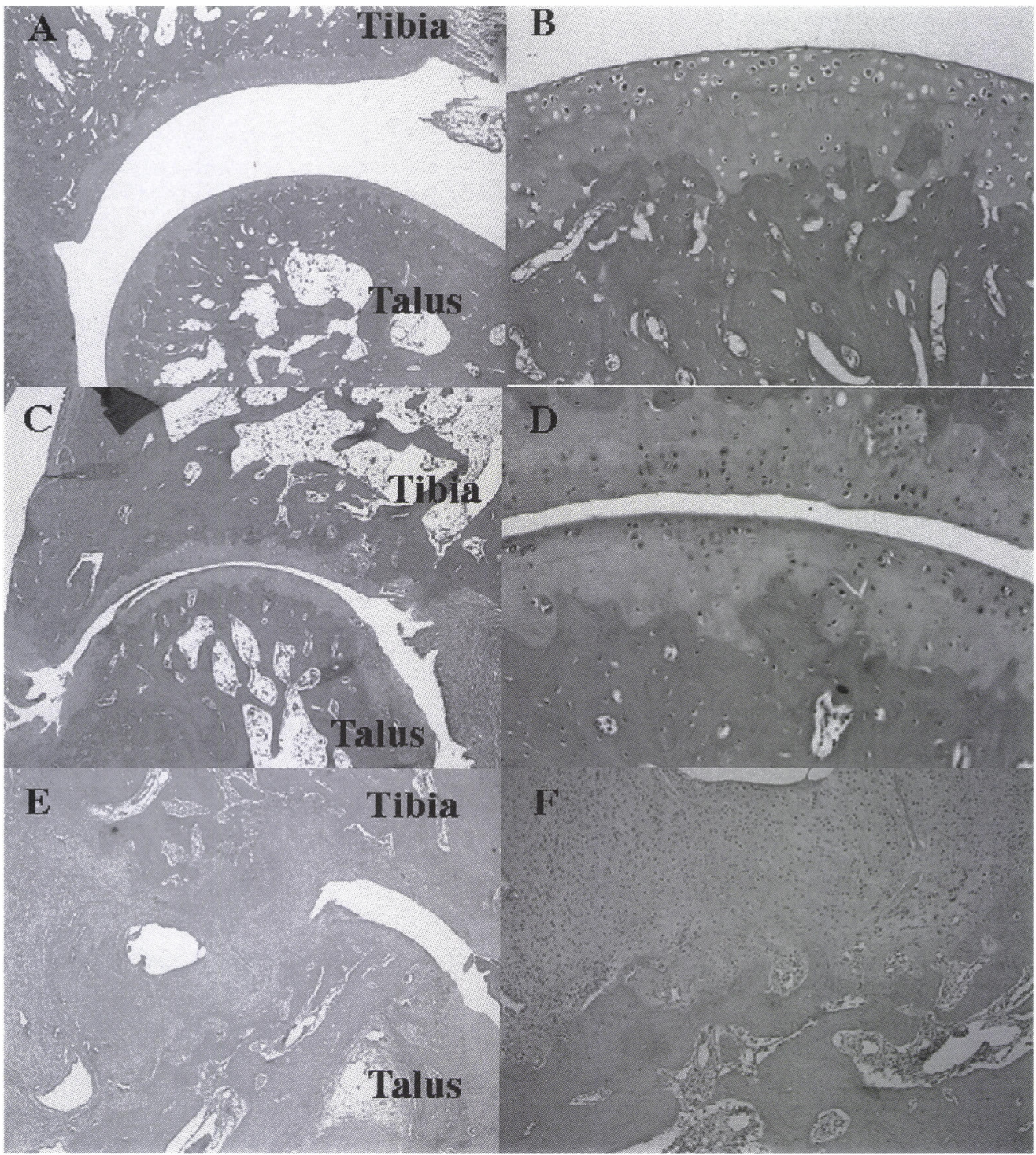

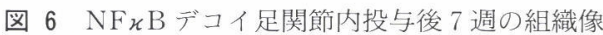

$\mathrm{NF} \boldsymbol{x} \mathrm{B}$ デコイ投与 $(\mathrm{C}, \mathrm{D})$ では関節軟骨の菲薄化は認められるがほぼ全周にわたり関節軟骨は温存され ている。スクランブルデコイ投与 $(\mathrm{E}, \mathrm{F})$ では著しい関節破壊が認められる。 A， B は健常ラットの足関 節組織像。（A， C, E × 40 倍, B, D, F $\times 100$ 倍)

胞外からの活性化刺激 ( IL $-1 \beta, \mathrm{TNF} \alpha$, 紫外線照 射など)により $\mathrm{I} \varkappa \mathrm{B}$ のリン酸化が起こり $\mathrm{I} \varkappa \mathrm{B}$ は

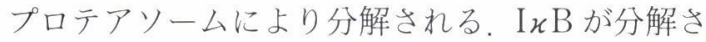
れることにより, $\mathrm{NF} \varkappa \mathrm{B}$ は核内へ移行しその標的 遺伝子の発現を活性化する(図 1) ${ }^{12,13)}$.

$\mathrm{RA}$ 増殖滑膜細胞での NF $\mathrm{NB}$ の活性化が報告 され,さまざまな炎症性サイトカインや接着因子 の発現が六進し病態形成や関節破壊における
$\mathrm{NF} \varkappa \mathrm{B}$ の重要性が示唆された ${ }^{14 \sim 16)}$. そこで筆者ら は転写因子レベルでの制御を目的としておとり (デコイ)型核酸医薬による治療法を考案した ${ }^{17)}$. これは特定の転写調節因子の結合部位の結合を阻 害し, 活性化される遺伝子群の発現抑制あるいは 発現増強を行うものである。そのため転写調節因 子の結合部位を含む短いオリゴヌクレオチドを合 成し，二重鎖核酸にしたあと細胞内に導入する。 
Day 21

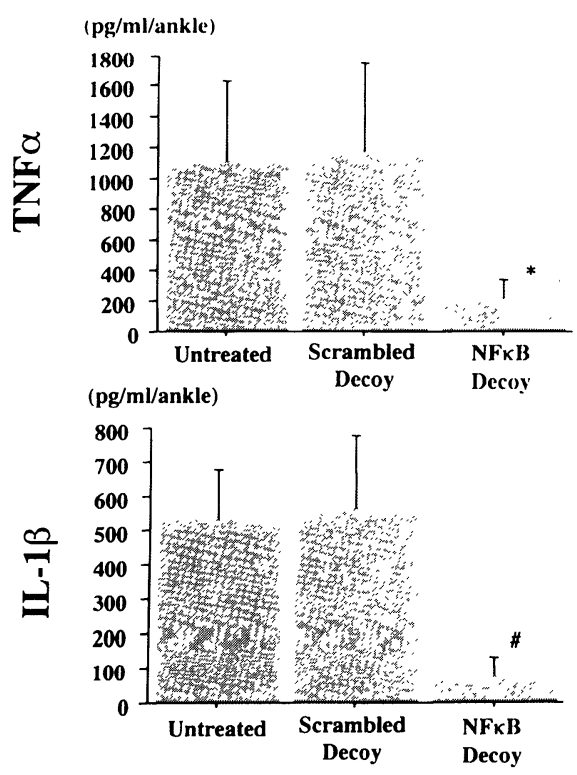

Day 6.3

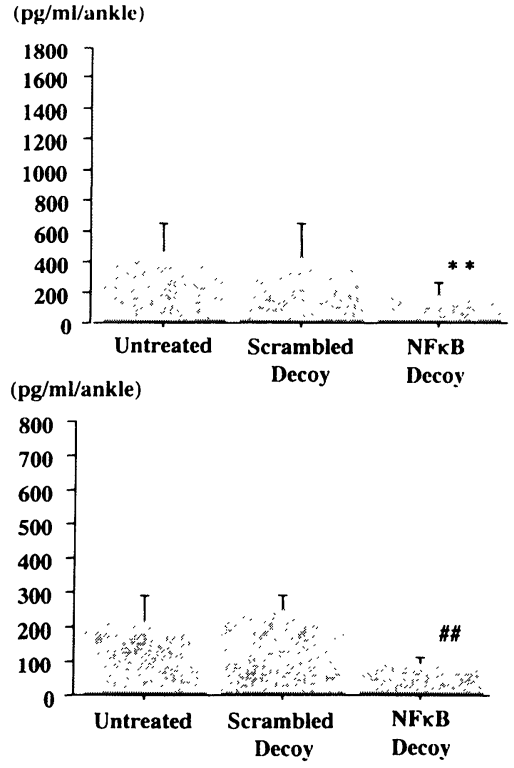

図 7 関節滑膜中の $\mathrm{IL}-1, \mathrm{TNF} \alpha$ 濃度 Day 21 (デコイ投与後 1 週), Day 63 (デコイ投与後 7 週) とも関節滑膜中の $\mathrm{TNF} \alpha$, IL $-1 \beta$ 濃度は NF $\varkappa$ B デコイ投与群で有意に抑制されていた。 * **, \#, \#\# p $<0.01 \mathrm{vs}$ scrambled decoy

そのメカニズムは明らかであり，転写調節因子の 結合部位への競合的結合阻害によるプロモーター 活性の低下である (図 2) ${ }^{18,19)}$.

\section{核酸医薬の関節内導入法の開発}

核酸医薬とは，核酸合成機で作成される短い核 酸を用いた人工化合物の総称であり，アンチセン スオリゴや上述のデコイなどが特定の遺伝子発現 抑制方法として注目されている。しかしこれら核 酸医薬は生体内では非常に不安定であり, 罹患関 節において核酸医薬を用いて特定遺伝子発現抑制 を行う場合，その効果を期待するにはまず安全で 効率のよい導入法の確立が必須である.

大阪大学では生体組織における遺伝子導入にす ぐれた方法として細胞融合に基づく遺伝子導入法 の研究から HVJ(hemmaglutinating virus of Japan : Sendai virus)リポゾーム法の開発が行わ れてきた ${ }^{20,21)}$. HVJ-リポゾーム法は遺伝子を核蛋 白と結合後, 脂質の膜に包み込み, DNA-脂質複合 体を形成したあと，不活化した HVJを加え HVJ の膜融合能を利用し, 遺伝子を直接細胞質へ導入
する方法である(図 3)，HVJの細胞表面レセプ ターはシアル酸のついた糖脂質, 糖蛋白質であり, リンパ球以外のほとんどの細胞に融合し遺伝子の 導入が可能である。筆者らは HVJ-リポゾーム法 を用い，関節内への直接投与によりこれまでに， 関節軟骨, 滑膜, 鞀帯への遺伝子導入に成功して いる22).

また HVJーリポゾームによる関節内での明らか な炎症反応, 組織傷害や免疫反応は認められず, 他の臓器での検討でも現在までのところ細胞毒性 や中和抗体に関しては他の導入法に比べきわめて 少ないと考えられている ${ }^{23)}$. 本法は核酸医薬の in vivoへの導入でもきわめてすぐれている年 27). 実 際に FITCラベルしたオリゴヌクレオチドを関 節炎モデルラットの関節内へ導入してみると, 増 殖滑膜細胞の核内にオリゴヌクレオチドが移行 し, 経時的にその発現は減少するものの導入後 28 日までは関節滑膜内に存在が認められた ${ }^{28)}$.オリ ゴヌクレオチドを $\mathrm{HVJ}$-リポゾーム法を用いずに 単独で関節内投与しても発現レベルは有意に低 く，また核内移行も少数しか認められず，ほぼ 24 


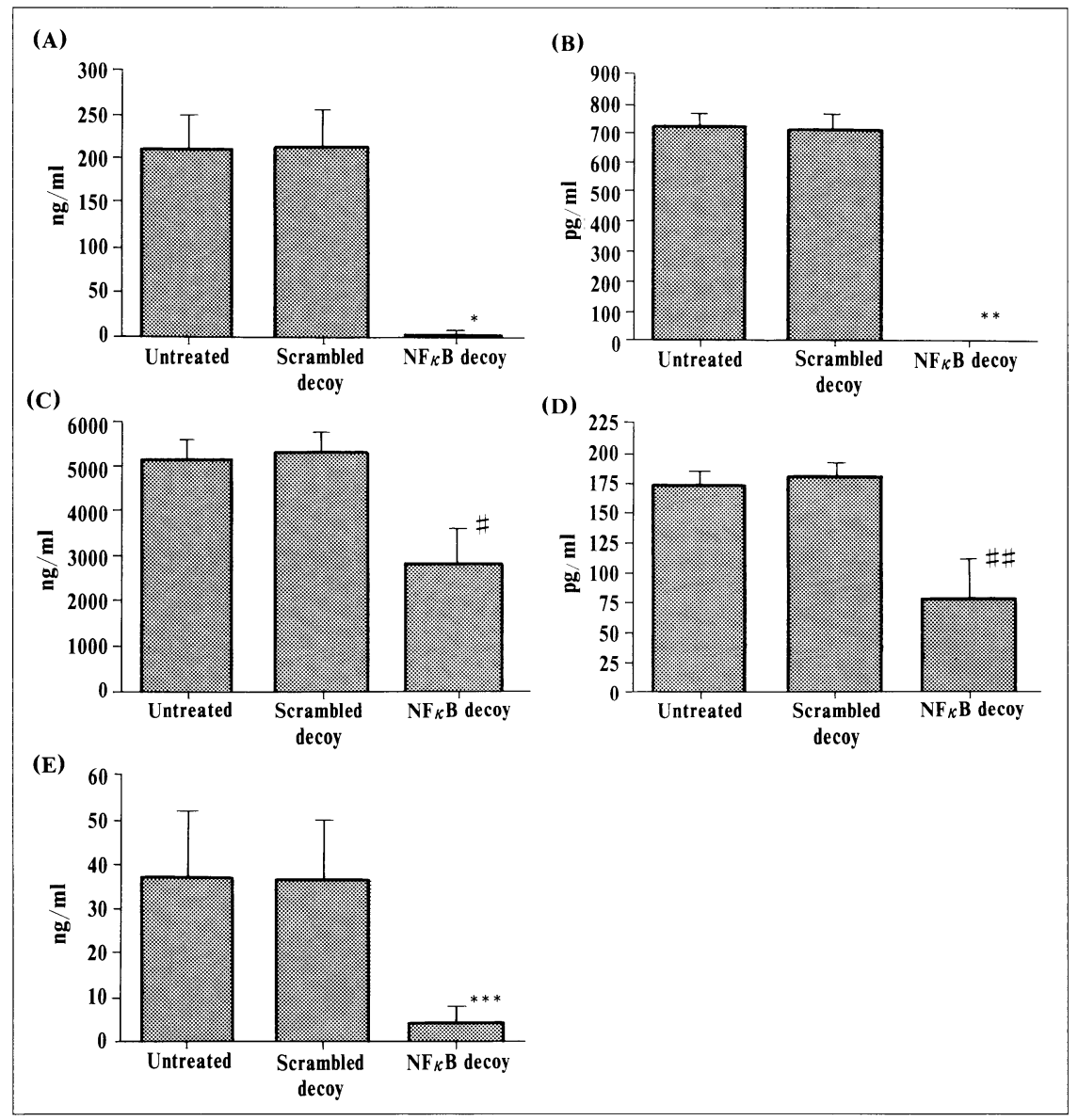

図 8 ヒト RA 滑膜組織に対する $\mathrm{NF} \varkappa \mathrm{B}$ デコイの影響

(A) IL-1 $\beta$, (B) TNF $\alpha, \quad$ (C) IL-6, (D) MMP-1, (E) ICAM-1. * , **, ${ }^{* * *} \mathrm{p}<0.01$ vs scrambled decoy, \#, \# $\mathrm{p}<0.05$ vs scrambled decoy

時間以内に大半が分解された。 また効果に関して も HVJ-リポゾーム法を応用することにより，よ り少量の核酸医薬で同等の遺伝子発現抑制効果が 得られしかもより長期にわたり効果を期待するこ とができた ${ }^{29,30)}$.

\section{転写因子制御による関節破壊抑制効果}

ラットコラーダン関節炎 (CIA) モデルを用いて $\mathrm{NF} \varkappa \mathrm{B}$ デコイによる治療効果を検討してみ た ${ }^{28)}$. CIA 関節滑膜における転写因子 $\mathrm{NF} \varkappa \mathrm{B}$ の 活性化について検討したところ，ヒト RA 滑膜細 胞と同様に CIA 関節滑膜でも $\mathrm{NF} \varkappa \mathrm{B}$ の活性化は 穴進していた。初回感作後 2 週で, 肉眼的に明ら かに関節炎を発症した足関節を対象として
$\mathrm{NF} \varkappa \mathrm{B}$ デコイを $\mathrm{HVJ}$-リポゾーム法を用い直接 関節内投与した。コントロールとしてスクランブ ルデコイを同様の方法で関節内投与した，関節腫 脹は投与後 2 週より $\mathrm{NF} \varkappa \mathrm{B}$ デコイ投与群でスク ランブルデコイ投与群や未治療群に比べ有意に改 善した (図 4). 投与後 7 週での検討では X 線学的 には $\mathrm{NF} \varkappa \mathrm{B}$ デコイ投与群では健常ラット足関節 に比べ関節裂隙の多少の狭小化は認められるが, 明らかな骨破壊は認められなかった。これに対し スクランブルデコイ投与群では足関節の破壊は明 らかであった(図 5).

同時に行った組織学的検討では $\mathrm{NF} \varkappa \mathrm{B}$ デコイ 投与群では健常ラットに比べ関節裂隙の狭小化, 関節軟骨の菲薄化を認めたが関節軟骨はほぼ全周 
にわたり温存されており，滑膜増殖はほとんど認 められなかった。 スクランブルデコイ投与群では 未治療群と同様であり，関節軟骨は完全に破壊さ れ軟骨下骨の破壊，パンヌスの形成は著明であっ た(図 6).

これらの結果は $\mathrm{NF} \varkappa \mathrm{B}$ デコイ投与により明ら かに関節破壊が抑制されたことを示している。そ の機序を検討する目的で，デコイ投与後 1 週およ び 7 週での関節滑膜中の IL-1,TNF $\alpha$ 濃度を測定 した。 どちらの時期においても関節滑膜中の IL$1, \mathrm{TNF} \alpha$ 濃度は $\mathrm{NF} \varkappa \mathrm{B}$ デコイ投与群でスクラン ブルデコイ投与群，未治療群に比べ明らかに抑制 されていた(図 7)。すなわち $\mathrm{NF} \varkappa \mathrm{B}$ デコイ投与に より $\mathrm{NF} \varkappa \mathrm{B}$ の活性化が阻害され，その下流にあ る IL-1，TNF $\alpha$ の遺伝子発現が抑制されたと考 えられる。

ついでヒト RA 滑膜組織や滑膜細胞を用いて $\mathrm{NF} \varkappa \mathrm{B}$ デコイの効果について検討した ${ }^{31)}$ ．滑膜組 織器官培養系で, $\mathrm{NF} \varkappa \mathrm{B}$ デコイを滑膜組織に導入 し, 滑膜組織からの IL-1, TNF $\alpha$, IL-6, MMP1の産生を測定した(図8)。これらの産生は $\mathrm{NF} \varkappa \mathrm{B}$ デコイ導入群でスクランブルデコイ導入 群，未治療群に比べ有意に抑制された。

血管新生などに重要な役割を果たすと考えられ ている接着分子である ICAM-1 の滑膜組織中で の発現についても検討したが，その発現も $\mathrm{NF} \varkappa \mathrm{B}$ デコイ導入により明らかに抑制された。これらの 抑制効果は特に IL-1，TNF $\alpha$ で顕著であった。 IL-1，TNF $\alpha$ が NF $\varkappa$ B デコイによりその発現が ほとんど抑制されるのに対し，IL-6，MMP-1で は発現抑制は約 60\%程度であった。これは IL-6, MMP-1 発現に AP-1 や NF-IL-6 など他の転写 調節因子の関与が存在するためと考えられた。培 養滑膜細胞に対しては $N F \varkappa B$ デコイ導入による 細胞増殖抑制効果も示されている。これは炎症性 サイトカインの発現低下に伴う二次的な効果と考 えられた。

\section{おわりに}

これまでの結果は $\mathrm{NF} \varkappa \mathrm{B}$ デコイによる $\mathrm{RA}$ 関 節破壊抑制の可能性を大いに示唆するものと考え
られた。.回は単回投与によりかなりの効果が得 られたが，RA は慢性疾患であり実際の臨床応用 では繰り返し投与が必要になる可能性があり，投 与方法，投与間隔などについての詳細な検討が必 要と考えられる，筆者らはすでに臨床応用に向け て大型動物による検討を開始している，筆者らは 滑膜増殖の観点からは細胞周期調節因子である $\mathrm{E} 2 \mathrm{~F}$ に対するデコイによりヒト RA 滑膜増殖を 抑制できることも報告しており ${ }^{32)}$ ， RA の病態形 成において重要な役割を果たしていると考えられ ている転写因子 AP-1 に対するデコイの有用性も 実験動物モデルで報告されている33.

現段階ではヒトに臨床応用するためにはまだま だ基礎的研究は必至であるが，転写調節因子レベ ルでの制御により RAの関節破壊を抑制できる 可能性が示唆されており，今後他の転写調節因子 を含めた RA の関節破壊機序の解明とその制御 を目的とした核酸医薬療法の治療への応用が期待 される。

\section{文 献}

1) Bathon J, Martin RW, Fleishman RM et al. : A comparison of etanercept and methotrexate in patients with early rheumatoid arthritis. N Engl J Med 343(22) : 1586-1593, 2000.

2) Elliott MJ, Maini RN, Feldmann $M$ et al. : Treatment of rheumatoid arthritis with chimeric monoclonal antibodies to tumor necrosis factor. Arthritis Rheum 36:1681-1690, 1993.

3) Piguet PF, Grau GE, Vesin C, Loetscher H, Gentz R, Lesslauer $\mathrm{W}$ : Evolution of collagen-induced arthritis in mice is arrested by treatment with anti-tumor necrosis factor(TNF) antibody or a recombinant soluble TNF receptor. Immunology $77: 510-514$, 1992.

4) Williams RO, Feldmann M, Maini RN : Anti-tumor necrosis factor ameliorates joint disease in murine collagen-induced arthritis. Proc Natl Acad Sci USA $89: 9784-9788,1992$.

5) Wooley PH, Dutcher J, Widmer MB, Gillis S : Influence of a recombinant human soluble tumor necrosis factor receptor FC fusion protein on type II collagen-induced arthritis in mice. J Immunol $151: 6602-6607,1993$.

6) Hung GL, Galea-Lauri J, Mueller GM et al. : Suppression of intra-articular response to interleukin1 by transfer of the interleukin-1 receptor antagonist gene to synovium. Gene Ther 1:64-69, 1994.

7) Otani K, Nita I, Macaulay W et al. : Suppression of antigen-induced arthritis in rabbits by ex vivo gene 
therapy. J Immunol 156:3558-3562, 1996.

8) Makarov SS, Olsen JC, Johnston WN et al. : Suppression of experimental arthritis by gene transfer of interleukin 1 receptor antagonist cDNA. Proc Natl Acad Sci USA 93:402-406, 1996.

9) Drevlow B, Capezio J, Lovis R et al. : Phase I study of recombinat human interleukin-1 receptor (RHU IL-1 R) administered intra-articularly in active rheumatoid arthritis. Arthritis Rheum 36 (suppl.) : S 39, 1993.

10) Bresnihan B, Lookabaugh J, Wilt $K$ et al. : Treatment with recombinant human interleukin-1 receptor antagonist ( $r$ IL-1 ra) in rheumatoid arthritis (RA). Arthritis Rheum 36(suppl.) : S 73, 1993.

11) Sen $R$, Baltimore $D$ : Inducibility of kappa immunoglobulin enhancer-binding protein Nf-kappa $\mathrm{B}$ by a posttranslational mechanism. Cell 26; 47 (6) : 921-928, 1986.

12) Collart MA, Baeuerle PA, Vassalli P : Regulation of tumor necrosis factor alpha transcription in macrophages : involvement of four $\mathrm{kB}$-like motifs and constitutive and inducible form of $\mathrm{NF} \varkappa \mathrm{B}$. Mol Cell Biol $10: 1498-1506,1990$.

13) Ghosh S, May MJ, Koppe EB : NF-kappa B and Rel proteins: evolutionarily conserved mediators of immune responses. Annu Rev Immunol 16: 225-260, 1998.

14) Fujisawa $\mathrm{K}$, Aono $\mathrm{H}$, Hasunuma $\mathrm{T}$ et al. : Activation of transcriptional factor $\mathrm{NF} \varkappa \mathrm{B}$ in human synovial cells in response to tumor necrosis factor a. Arthritis Rheum 39: 197-203, 1996.

15) Handel ML, McMorrow LB, Gravallese EM : Nuclear factor ${ }^{-} \varkappa \mathrm{B}$ in rheumatoid synovium. Localization of p 50 and p 65. Arthritis Rheum 38 : 1762-1770, 1995.

16) Marok R, Winyard PG, Coumbe A et al. : Activation of the transcription factor nuclear factor $x \mathrm{~B}$ in human inflamed synovial tissue. Arthritis Rheum 39 : 583-591, 1996.

17) Morishita R, Sugimoto $T$, Aoki $M$ et al. : In vivo transfection of cis element "decoy" against nuclear factor $\varkappa \mathrm{B}$ binding site prevents myocardial infarction. Nat Med 3:894-899, 1997.

18) Tomita N, Morishita R, Higaki J et al. : A novel strategy for gene therapy and gene regulation analysis using transcripational factor decoy oligonucleotides. Exp Nephrol 15:429-434, 1997.

19) Tomita N, Morishita R, Kaneda $Y$ et al. : Gene therapy as a potential treatment for restenosis and myocardial infarction. Drug News Perspect 13 : 206-212, 2000.

20) Kaneda $Y$, Iwai $K$, Uchida $T$ : Increased expression of DNA cointroduced with nuclear protein in adult rat liver. Science $20 ; 243(4889): 375-378,1989$.

21) Kaneda $Y$, Iwai $K$, Uchida $T$ : Introduction and expression of human insulin gene in adult rat liver. J Biol Chem 264:12126-12129, 1989.
22) Tomita $\mathrm{T}$, Hashimoto $\mathrm{H}$, Tomita $\mathrm{N}$ et al. : In vivo direct gene transfer into articular cartilage by intraarticular injection mediated by $\mathrm{HVJ}$ (Sendai virus) and liposomes. Arthritis Rheum 40 : 901906, 1997.

23) Dzau VJ, Mann MJ, Morishita R et al. : Fusigenic viral liposome for gene therapy in cardiovascular disease. Proc Natl Acad Sci USA $93: 11421^{-}$ 11425, 1996.

24) Morishita R, Gibbson GH, Horiuchi M et al. : A novel molecular strategy using cis element "decoy" of E $2 \mathrm{~F}$ binding site inhibits smooth muscle proliferation in vivo. Proc Natl Acad Sci USA 92: 5855-5859, 1995.

25) Morishita R, Higaki J, Tomita $N$ et al. : Role of transcriptional cis-elements, angiotensinogen geneactivating elements, of angiotensinogen gene in blood pressure regulation. Hypertension $27: 502-$ 507, 1996.

26) Morishita R, Gibbson GH, Ellison KE et al. : Single intraluminal delivery of antisense cdc 2 kinase and PCNA oligonucleotides results in chronic inhibition of neointimal hyperplasia. Proc Natl Acad Sci USA $90: 8474-8479,1993$.

27) Tomita N, Morishita R, Higaki J et al. : Transient decrease in high blood pressure by in vivo transfer of antisense oligodeoxynucleotides against rat angiotensinogen. Hypertension 26:131-136, 1995.

28) Tomita $T$, Takeuchi $E$, Tomita $\mathrm{N}$ et al. : In vivo transfection of $\mathrm{NF} \varkappa \mathrm{B}$ decoy oligodeoxynecleotides suppressed the severity of collagen-induced arthritis as a gene therapy. Arthritis Rheum 42:25322542, 1999.

29) Morishita R, Gibbons GH, Ellison KE et al. : Intimal hyperplasia after vasculari injury is inhibited by antisense cdk 2 kinase oligonucleotides. J Clin Invest $93: 1458-1464,1994$.

30) Morishita R, Gibbons GH, Kaneda $Y$ et al. : Pharmacokinetics of antisense oligonucleotides (cyclin B 1 and cdk 2 kinase) in the vessel wall: Enhanced therapeutic utility for restenosis by $\mathrm{HVJ}$-liposome method. Gene 149:13-19, 1994.

31) Tomita $\mathrm{T}$, Takano $\mathrm{H}$, Tomita $\mathrm{N}$ et al. : Transcription factor decoy for $\mathrm{NF} \varkappa \mathrm{B}$ inhibits cytokine and adhesion molecule expression in synovial cells derived from rheumatoid arthritis. Rheumatology $39: 749-757,2000$.

32) Tomita $\mathrm{T}$, Takano $\mathrm{H}$, Tomita $\mathrm{N}$ et al. : Oligonucleotide decoy for transcriptional factor E2 F inhibits RA synovial cell proliferation in vitro. Arthritis Rheum 42 (suppl.) : S 107, 1999.

33) Shiozawa S, Shimizu K, Tanaka K et al. : Studies on the contribution of $\mathrm{c}-\mathrm{fos} / \mathrm{AP}-1$ to arthritic joint destruction. J Clin Invest $99:$ 1210-1216, 1997. 